


Parte I - O Direito comparado e seus Protagonistas: QuAL uso, PARA QUAL FIM, COM QUAIS MÉTODOS? .....................................................................1

EDITORIAL ............................................................................................................... 3

"Tudo o que precisamos fazer é ter certeza de que continuaremos conversando".............................. 3

Gustavo Cerqueira e Patrícia Perrone Campos Mello

Direito comparado E METOdologia $\quad$................................................... 6

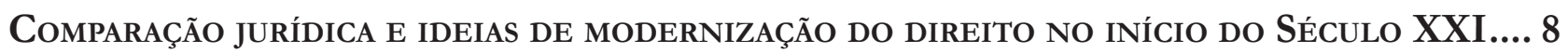
Gustavo Cerqueira

O DIREITO COMPARADO: ESFORÇO DE RESGATE HISTORIOGRÁFICO E DE PROBLEMAS METODOLÓGI$\cos$

Arnaldo Sampaio de Moraes Godoy e Gustavo Fereira Ribeiro

Direito Comparado e Política: Reflexões Necessárias .42

Raphael Carvalho de Vasconcelos e Deo Campos Dutra

Direito comparado no Brasil

L'originalité du Droit Brésilien et le Droit Comparé .57

Arnoldo Wald

LEI DA BOA RAZÃo E COMPARATISMO JURÍDICO NA DOUTRINA CIVILISTA BRASILEIRA DE 1850 A 1880

Alan Wruck Garcia Rangel

O STF EM REDE? QUANTO, COMO, COM QUE ENGAJAMENTO ARGUMENTATIVO O STF USA PRECEDENTES ESTRANGEIROS EM SUAS DECISÕES?

Patrícia Perrone Campos Mello e Felipe Meneses Graça 
Suprema Imprecisão: a metodologia em Direito Constitucional Comparado E as deficiênCias Em Seu uso pelo Supremo Tribunal Federal

Alonso Freire e Hugo Sauaia

Direitos comparados

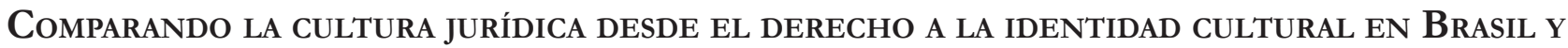

CHILE 145 Juan Jorge Faundes e Fabian Le Bonniec

O Divino e o Racional no Direito: notas para um diálogo entre sistemas jurídicos 181 Salem Hikmat Nasser e José Garcez Ghirardi

Regulação do discurso de Ódio: análise comparada em países do Sul Global 196 Jane Reis Gonçalves Pereira, Renan Medeiros de Oliveira e Carolina Saud Coutinho

Parte II - Outros temas

LA OTRA CARA DE LA MONEDA: PROTECCIÓN CONSTITUCIONAL DE LA EMPRESA, EL EMPRENDIMIENTO Y LA LIBRE COMPETENCIA EN CHILE y COLOMBiA

Juan Pablo Díaz Fuenzalida e Juan Sebastián Villamil Rodríguez

The European Court of Human Rights Decision on there 'Burqa Ban'and the CritiCal analysis of the Pragmatic experimental logic 258 Flavianne Fernanda Bitencourt Nóbrega e George Browne Rego

Direitos humanos das deslocadas ambientais e os impactos da Usina de Belo Monte: da EXPLORAÇÃO AMAZÔNICA À SUBJUGAÇÃO FEMININA

Thais Silveira Pertille e Letícia Albuquerque

Solução de Controvérsias em Acordos de Investimento: as experiênCias do CPTPP, CETA E DOS ACFIs

Fábio Morosini, Vivian Daniele Rocha Gabriel e Anastacia Costa

50 anos dos “direitos da Criança” na Convenção Americana de Direitos Humanos: a HISTÓRIA DO ARTIGO 19 311

Sven Peterke e Paloma Leite Diniz Farias 
EMPRESAS E DIREITOS HUMANOS: COMPARTILHANDO VALOR E RESPONSABILIDADES .325 Melina Girardi Fachin

CONTEMPORARY RESPONSES TO BUSINESSES' NEGATIVE HUMAN RIGHTS IMPACT 341 Andres Felipe Lopez

Human Right to LABOR PROTECTION IN UKRAINE: CURRENT SITUATION AND THE PROSPECTS OF IMPLEMENTATION OF INTERNATIONAL RULES 363 Nina Daraganova

International Regulation and Global Governance: The EU influential Method IN TIMES OF NORMATIVITY CHANGE 373 Gabriela Hühne Porto, Paula Wojcikiewicz Almeida e Juliana Maia F. A. Netto

Tecnologias digitais e o comércio de bens E SERviços na OMC/Digital. 391 Umberto Celli Junior

Los fuertes hacen lo QUe PUeden: exponiendo los límites de la Corte Penal InternaCIONAL .406

Cristián D. González-Ruiz e Víctor M. Mijares

Human Rights, Humanitarian Law and State Power 418 Renata Nagamine e João Roriz

Regional integration in the South Pacific: Challenges for Public governance .433 Joanna Siekiera

Parte III - Resenhas 443

RESENHA DA OBRA

“Democracia e policentrismo do poder", de Murilo Gaspardo 445 Angela Limongi Alvarenga Alves 


\section{International Regulation and Global Governance: The EU influential method in times of normativity change*}

\section{Regulação Internacional e Governança Global: o método influencial da UE em tempos de mudança normativa}

* Recebido em 09/08/2019

Aprovado em 19/04/2020

** Bachelor of Law from the University of the State of Rio de Janeiro (UERJ); Master's degree in International Law at the UERJ Graduate Program. Since 2016, she has worked as a research assistant in International and European Law at FGV Direito Rio, curently, in the FGV Jean Monnet Centre of Excellence on EU-South America Global Governance. Email: gabriela.porto@fgv.br

*** Professor of International Law and EU Law, Getulio Vargas

Foundation Law School in Rio de Janeiro (since 2008). Director of the Jean Monnet Centre of Excellence on EU-South America Global Governance, sponsored by the European Commission at the Getulio Vargas Foundation Law School. Associate Researcher at the Institute of International and European Law at the Sorbonne (IREDIES). Professor of the Post-Graduate Programs of the Getulio Vargas Foundation Law School and of the Masters in International Relations of the Faculty of Social Sciences, Getulio Vargas Foundation in Rio de Janeiro. Qualified as 'maittre des conferences' in Public Law (France, CNU). Elected Brazilian Member of the International Law Association Committee on the Procedure of International Courts and Tribunals. Chair of the Interest Group on 'International Courts and Tribunals' of the Latin American Society of International Law (LASIL). Doctorate with honors summa cum laude in International and European Law at the Université Paris 1 Panthéon-Sorbonne (mention très honorable avec les félicitations du jury à l'unanimité, recommandé à des prix de thèse et à des subventions à la publication). Masters of Law (Master II Recherche - former DEA) in Public International and European Law - Université Paris XI, Faculté Jean Monnet. Post-doctoral visiting scholar at the Max Planck Institute for Comparative Public Law and International Law (2014). Visiting professor at the École de droit de la Sorbonne, Université Paris 1 Panthéon- Sorbonne (2019). Email : paula.almeida@fgv.br

**** Undergraduate student of Law from Fundação Getulio Vargas, Rio de Janeiro (FGV Direito Rio). Email: juliana.maiaferreira@ gmail.com

\author{
Gabriela Hühne Porto** \\ Paula Wojcikiewicz Almeida**** \\ Juliana Maia F. A. Netto****
}

\section{Abstract}

This article intends to access the role of governance reforms as a response to the challenges raised by the expansion of normative powers in International and European legal orders. Arguably, traditional legal categories have ceased to adequately reflect the actual stage of economic, social and legal cross-border relations within multiples actors and interests. Changes in International and European law-making are indeed noticeable and result in many regulatory challenges derived from the increased participation of nonstate actors. These changes produce impact via soft law instruments, such as recommendations, guidelines, non-binding agreements and reports. Particularly, for decision-making processes involving public interest, questions of legitimacy and accountability are frequently raised in the exercise of authority. In spite of the European Union's particular structure, the challenges concerning the division and allocation of authority at the EU level are common to those reflected at the international level. In the last decades, there has been an "evolution" in the EU Governance, including the development of good and multilevel governance mechanisms. By implementing a deductive method, this article aims to access to what extend the EU institutional response can encourage and inspire the accommodation of the international legal order to the current normativity changes.

Keywords: International Regulation; Global Governance; Good Governance; Legitimacy, Accountability; European Union, Non-State Actors; Soft Law.

\section{Resumo}

Este artigo pretende acessar o papel das reformas de governança como resposta aos desafios levantados pela expansão dos poderes normativos nas ordens jurídicas internacionais e europeias. Possivelmente, as categorias jurídicas tradicionais deixaram de refletir adequadamente o estágio real das relações econômicas, sociais e jurídicas transfronteiriças entre múltiplos ato- 
res e interesses diversos. Mudanças no processo legislativo internacional e europeu são de fato percetíveis e geram diversos desafios regulatórios, derivados da maior participação de atores não estatais e do impacto de instrumentos de soft law, como recomendações, diretrizes, acordos e relatórios não vinculativos. Particularmente para processos de tomada de decisão envolvendo interesse público, questões de legitimidade e responsabilidade são levantadas no exercício da autoridade. Apesar da estrutura específica da União Europeia, os desafios relativos à divisão e alocação de autoridade no nível europeu são semelhantes aos internacionais. Nas últimas décadas, houve uma "evolução" na governança da UE, incluindo o desenvolvimento de mecanismos de governança boa e multinível. Ao implementar o método dedutivo, este artigo visa acessar até que ponto a resposta institucional da UE pode encorajar e inspirar a acomodação da ordem jurídica internacional às atuais mudanças normativas.

Palavras-chave: Regulação Internacional; Governança Global; Boa Governança, Legitimidade, Accountability; União Europeia, Non-State Actors; Soft Law.

\section{Introduction}

The bursting of geopolitical frames following globalization reveal de-territorialized forms of power and fragmented state sovereignty ${ }^{1}$. Changes in the normative, political and economic environment inspire new patterns of allocation of public authority and "informal" exercise of power at the global level ${ }^{2}$. Traditional legal categories have ceased to adequately reflect the actual stage of economic, social and legal cross-border relations within multiples actors and interests. Changes in International and European law-making are indeed noticeable and result in many regulatory challenges derived from the increased participation of Non-State Actors (NSAs). As far as International Law is concerned, there appears to exist a detachment from traditional in-

\footnotetext{
See WATT, HORATIA MUIR. "Party Autonomy" in international contracts: from the makings of a myth to the requirements of global governance. European Review of Contract Law n. 3, 2010, p. 9.

2 See BORBOSA, Luiza Nogueira; MOSCHEN, Valesca R. B. O direito transnacional ("global law") e a crise de paradigma do estadocentrismo: é possível conceber uma ordem jurídica transnacional? Revista de Direito Internacional, v. 13, n. 3, 2016, p. 147.
}

ternational law-making ${ }^{3}$ and an erosion of the fine line that separate the Public International Law field from other types of regulation in the global arena ${ }^{4}$.

These changes in the global arena, not necessarily addressed by instruments derived from Public International Law, produce impact via soft law instruments, such as recommendations, guidelines, non-binding agreements and reports. There is no doubt that the increased participation of NSAs and the impact of soft law instruments overcome the scope of classical International Law tools, which no longer respond to global regulatory challenges. In this line, many decision-making processes and regulatory rules that used to be exclusively produced by national legislators have now shifted to the global level with the participation of NSAs. This reality has incited debates around issues of legitimacy and accountability in the exercise of authority by NSAs.

In this context, the broad concept of global governance helps to understand the globalized legal structure and also the place for International Law within this structure ${ }^{5}$. However, this concept remains disputed in academia. Esty believes that the global governance debate means shifting from a state-centric view to a globalized system of checks and balances that limits national government's political mistakes ${ }^{6}$. To Weiss, the governance purpose is the provision of collective efforts to address "worldwide problems that go beyond the problem-solving capacity of States". Von Bodgandy claimed that definitions should not focus exclusively on the actors, but also on their exercises of public authority ${ }^{8}$. In the same line, Zurn states that "global governance refers to the exercise of

D'ASPREMONT, J. Non-state actors in international law: oscillating between concepts and dynamics. In: D'ASPREMONT, J. (ed.). Participants in the International Legal System. Abingdon: Routledge, 2011, p. 326.

4 NASSER, Salem H.. Direito Global em Pedaços: Fragmentação, Regimes e Pluralismo. Revista de Direito Internacional, v. 12, n. 2, 2015, p. 109-110, 128.

5 VOLPON, Fernanda; RIBEIRO, Marilda Rosado de Sá. Desa os da governança energética global e a participação do brics na construção de um novo paradigma energético. Revista de Direito Internacional, v. 15, n. 1, 2018, p. 202-205.

6 ESTY, Daniel. Good Governance at the Supranational Scale: Globalizing Administrative Law. New Haven: Yale Law Journal, 2006. pp. 1578-79

WEISS, Thomas G.; SEYLE, Conor D.; COOLIDGE, Kelsey. The Rise of Non-State Actors in Global Governance Opportunities and Limitations. One Earth Future Foundation, 2013. p. 6 8 See VON BOGDANDY, Armin; PHILIPP, Dann; GOLDMAN, Matthias. Developing the Publicness of Public International Law: Towards a Legal Framework for Global Governance Activities. German Law Journal, 2009. p. 1380 
authority across national borders as well as consented norms and rules beyond the nation state, both of them justified with reference to common goods or transnational problems"'.

Therefore, an analysis of the exercise of authority in the international scenario enable a better evaluation of international regulation as a whole. Von Bogdandy, Dann and Goldmann define 'exercise of authority' as any governance activity developed by an international institution that affects or limits the freedom of any other individual, state or institution ${ }^{10}$. Currently, normative authority is no longer exercised by a closed circle of high-ranking agents representing states, but has become an aggregation of complex procedures involving also new participants ${ }^{11}$. Authority is now exercised by new participants, with complex structures and procedures ${ }^{12}$. According to Bas Arts, Global Governance encompasses both intergovernmental and transnational mechanisms, including state regulation, mixed regulation (by States and NSAs) and private self-regulation (by NSAs only) ${ }^{13}$.

Taking this context into account, the current article intends to access the role of governance reforms as a response to the challenges raised by the expansion of normative powers in International and European legal orders. Indeed, alternative exercises of normative authority at both international and supranational levels have raised democratic concerns. As far as the European Union is concerned, several reforms were adopted in its model of governance in the last decades, including the development of good and multilevel governance mechanisms. Therefore, one may wonder whether the EU response can encourage and inspire the accommodation of the international legal order to the current normativity changes.

\footnotetext{
ZURN, Michael. A Theory of Global Governance: Authority, Legitimacy, and Contestation. Oxford University Press, 2018, p. 4.

10 VON BOGDANDY, Armin; PHILIPP, Dann; GOLDMAN, Matthias. Developing the Publicness of Public International Law: Towards a Legal Framework for Global Governance Activities. German Law Journal, 2009. p. 1376

${ }_{11}$ d'ASPREMONT, Jean. Non-State Actors in International Law: Oscillating between Concepts and Dynamics. Routledge, 2011. p. 4

12 d'ASPREMONT, Jean. Non-State Actors in International Law: Oscillating between Concepts and Dynamics. Routledge, 2011. p. 4

13 ARTS, Bas. Non-State Actors in Global Governance: Three Faces of Power. Max-Planck-Projektgruppe Recht der Gemeinschaftsgüter, 2003. p. 11
}

This article will first proceed with an analysis of the manner in which NSAs can influence the law-making and regulatory processes in the international legal system, as well as the challenges that permeate the process of expanding normative powers in the international order (2); in order to assess the role of EU governance reforms as a response to the challenges raised by the expansion of normative powers in International Law (3).

\section{The shift of authority beyond the state: the multiplicity of agents and interests in contemporary international law-making}

The contemporary global order presents a multiplicity of agents and interests, which constitute complex economic, social and legal cross-border relations ${ }^{14}$. Since States do not possess the resources to individually offer regulatory responses to all global challenges, other participants and organizations have increasingly incorporated normative functions in international regulation (2.1). This process produces benefits, but also bears some dilemmas, such as legitimacy claims and the lack of accountability mechanisms in most international bodies (2.2).

\subsection{The normative contribution of NSAs}

The global governance system presupposes the contribution of NSAs in dealing with the provision of common goods and transnational problems. Although the presence of NSAs is not a new phenomenon, their role has become more prominent in recent decades with globalization and increased privatization of government domains ${ }^{15}$. Indeed, the rise of functional regimes, hybrid actors and private legislators produce a noteworthy impact in the processes of rule-making and

\footnotetext{
14 XAVIER JUNIOR, Ely Caetano; BRANDÃO, Clarissa. Desafios Globais Contemporâneos: Cenário de Convergências no Direito Internacional. Revista Direito GV 5(2), 2009, p. 425.

15 INTERNATIONAL LAW ASSOCIATION, Report: non state actors. Johasnnesburg Conference (2016); Professor Math Noortmann (UK): Chair; Dr Veronika Bilkova (Czech Republic): Rapporteur, p. 8. See also BORBOSA, Luiza Nogueira; MOSCHEN, Valesca R. B. O direito transnacional ("global law") e a crise de paradigma do estado-centrismo: é possível conceber uma ordem jurídica transnacional? Revista de Direito Internacional, v. 13, n. 3, 2016, p. 147.
} 
decision-making ${ }^{4}$.

International law-making has also been affected by the increase of NSAs' participation. Although States remain the main actors of international relations ${ }^{16}$, this new scenario requires scholars to tackle not only how these NSA can be defined, but also, how can they fit in the current global governance structure.

There is no official definition of NSAs, nor a specific provision that limits their role in international law-making. The International Law Association (ILA), for example, proposes that these are entities, not controlled by States, capable of playing a major role in decision and policymaking in the international arena ${ }^{17}$. The European Commission grants a similar concept and defines NSAs as a range of organizations, created voluntarily, that involve different structures of the society, outside governments and public administration organs, in order to promote interests ${ }^{18}$.

Some contest the inclusion of Intergovernmental Organizations (IOs) in the concept of NSAs, since, they are composed by States and are usually associated with their interests; while others debate whether entities considered illegitimate or illegal, such as pirate groups and armed opposition groups, should be included in this concept $\mathrm{t}^{19}$. Nonetheless, if definitions may differ, these multiple concepts present at least two common ideas: (i) their independence from governmental structures, and (ii) their relevant impact on the international legal system.

It is a fact that NSAs are increasingly engaging in international law-making processes, and some might even have more power than an average State party ${ }^{20}$. That

16 NASSER, Salem H.. Direito Global em Pedaços: Fragmentação, Regimes e Pluralismo. Revista de Direito Internacional, v. 12, n. 2, 2015, p. 113.

17 INTERNATIONAL LAW ASSOCIATION. Committee on Non-State Actors Report of the 2016 Johannesburg Conference. p. 3

18 Communication from the Commission to the Council, the European Parliament and the Economic and Social Committee, Participation of Non-State Actors in EC Development Policy(Brussels, 07.11.2002, COM(2002) 598 final) 5

19 For further details, see INTERNATIONAL LAW ASSOCIATION. Committee on Non-State Actors Report of the 2016 Johannesburg Conference; INTERNATIONAL LAW ASSOCIATION. Committee on Non-State Actors Report of the 2012 Sofia Conference; and INTERNATIONAL LAW ASSOCIATION. Committee on Non-State Actors Report of the 2010 Hague Conference.

20 ZYBERI, Gentian. Non-State Actors from the Perspective of the International Law Commission. Routledge, 2011. p. 167 leads us to question the current organization of global governance, and how new institutions, such as NGOs (Non-Governmental Organizations) and multinational companies, may act in the system while creating benefits for global governance.

Decisions adopted by NSAs are usually included in the category of soft-law instruments ${ }^{21}$, being of a declaratory nature. However, they may still constitute important instruments of enforceability in the international system due to their capacity to influence State's behaviour and conduct. Also, non-binding rules established by NSAs may, eventually, result in binding legal rules ${ }^{22}$. In this view, Bas Arts presents three faces of power that might be exercised by NSAs: (i) decisional power; (ii) discursive power, and (iii) regulatory power ${ }^{23}$.

In practice, NSAs usually engage in or influence the drafting of international treaties, such as the case of the Geneva Conventions, in which the International Committee of the Red Cross (ICRC) approved Article 4(g), therefore creating the duty to work towards a "dissemination of knowledge of international humanitarian law in armed conflicts". Likewise, in 1992, a committee was formed to launch the International Campaign to Ban Landmines (ICBL). The group, that is now composed of over 1,300 NGOs operating at the national and international levels, succeeded in approving the 1997 Ottawa Mine Ban Treaty (The Convention on the Probibition of the Use, Stockpiling, Production and Transfer of Anti-Personnel Mines and on their Destruction). The ICBL organized a working group responsible for encouraging the ratification, implementation and strengthening of the Mine Ban Treaty. NSAs were also known to have significant roles in the development of the 1998 Rome Statute of the International Criminal Court and in the Convention of the Rights of the Child. Those are clear examples of NSAs exercising both their decisional and discursive powers ${ }^{24}$.

21 The Statute of the International Court of Justice, Article 38 (1), provides a list of sources of public international law, understood as primary and subsidiary sources. While the first are formal sources, such as treaties, international customs and general principles of law, the latter are related to non-binding instruments, such as jurisprudence.

22 GIERTL, Adam; LAZOECAKOVÁ, Tímea. The Role of Non-Governmental Organizations in International Law-making. IX CYIL, 2018. p. 47.

23 ARTS, Bas. Non-State Actors in Global Governance: Three Faces of Power. Max-Planck-Projektgruppe Recht der Gemeinschaftsgüter, 2003.

24 the International Committee of the Red Cross (ICRC) approved Article $4(\mathrm{~g})$, therefore creating the duty to work towards a "dissemina- 
Furthermore, NSAs are able to influence the construction of general principles of law. They can lead States to introduce certain norms in their domestic system in order to analyse whether they could be considered as a general principle. Additionally, they might influence a court to consider a certain provision as a generally accepted principle by the international community ${ }^{25}$.

It is also known that, due to their technical expertise, NSAs are commonly invited to participate in decision-making processes. Indeed, NSAs are also important participants in the decision-making processes in international bodies. For instance, many UN Secretariat departments have ongoing working relationships with NGOs, in order to supplement their limited information and resources ${ }^{26}$. Another example of the capacity of NSAs to make legal commitments concerns the elaboration of codes of conduct, voluntarily adopted by MNEs (Multinational Enterprises), to create corporate social responsibility and to guarantee the protection of human and environmental rights ${ }^{27}$.

Notwithstanding, despite NSAs relevance in today's globalized structure, global governance also faces challenges. Due to the expansion of global normativity, the line between international/domestic rule-making and decision-making is as fine as the borders between nations, and there are no clear boundaries between institutional competences ${ }^{28}$. In this context, the increased participation of NSAs inevitably highlights problems related to legitimacy, enforcement and accountability at the global level.

\subsection{The normative challenges of NSAs' exercise of public authority}

The idea that States have (implicitly) derogated some of their competences to international bodies, such as the World Bank and the International Monetary Fund (IMF) is now part of the global dynamic. International bodies, including

tion of knowledge of international bumanitarian law in armed conflicts".

25 INTERNATIONAL LAW ASSOCIATION. Committee on Non-State Actors Report of the 2016 Johannesburg Conference. p. 11

26 INTERNATIONAL LAW ASSOCIATION. Committee on Non-State Actors Report of the 2012 Sofia Conference. p. 12

27 INTERNATIONAL LAW ASSOCIATION. Committee on Non-State Actors Report of the 2012 Sofia Conference. p. 5

28 ALVAREZ, Jose E. The New Treaty Makers. Boston: Boston College International \& Comparative Law Review, 2002. p. 214
NSAs, have indeed acquired significant roles in global regulation in the recent years ${ }^{29}$. The rupture of the traditional state monopoly in the exercise of public authority opened the floor to intense criticism concerning the legitimacy and accountability deficits in the current regulatory systems. As a response, interested institutions are looking for mechanisms to boost their legitimacy, to guarantee the effectiveness and accountability of their decisions and to implement good governance practices $^{30}$.This section aims to assess the outcome of constant tensions caused by the shift of authority beyond the state, including legitimacy (2.2.1) and accountability (2.2.2) concerns in the current international law-making process.

\subsubsection{Legitimacy}

The idea of legitimacy is usually associated with "the right to rule". In this sense, a legitimate institution or court would have the justifiable right to establish rules, issue judgments and elaborate opinions that will be taken in due consideration by the international legal system ${ }^{31}$. As Andersen puts it, legitimacy is "the quality of a political order to be able to act with the broad and largely unquestioning support of its members" 32 . The legitimation process is composed by actors who seek justifications related to their interests, practices and institutional designs. These justifications constitute the so-called "legitimacy claims" 33 .

It is important to note, however, that legitimacy can be understood through two different perspectives: via a sociological and/or a normative lens. On the one hand, normative legitimacy derogates from the idea that a particular institution has the right to rule on a specific mat-

29 POSTIGA, Andréa Rocha. A emergência do direito administrativo global como ferramenta de regulação transnacional do investimento estrangeiro direto. Brasília: Revista de Direito Internacional, 2013. p. 174

30 The Global Administrative Law literature offers rich contributions in this matter. See, for example: KRISCH, Nico; KINGSBURY, Benedict. The Emergence of Global Administrative Law. In: Law and Contemporary Problems, vol. 68, 2005, p. 15-61.

31 COHEN, Harlan G; FOLLESSAL, Andreas; GROSSMAN, Nienke; ULFSTEIN, Geir. Legitimacy and International Courts - A Framework. Cambridge: Cambridge University Press, 2017. p. 3 32 ANDERSON, Kenneth. Global Governance: The Problematic Relationship between Global Civil Society and the United Nations. WCL Research Series, 2008

33 REUS-SMIT, Christian. International Crises of Legitimacy. International Politics, 2007. p. 159 
ter $^{34}$; while, on the other hand, sociological legitimacy is much more associated with public belief ${ }^{35}$. If a state does not believe in a particular international institution, it most likely will not cooperate with the decisions rendered by it. In other words, if an institution is being discredited due to the lack of its normative legitimacy, the debate is not whether others believe it has the right to rule, but whether it has the right to rule ${ }^{36}$.

By contrast, the debate surrounding sociological legitimacy relates to the idea of public legitimacy, and whether the mass public believe that a court or institution has the right to exercise its authority in a certain domain $^{37}$. These distinct approaches to legitimacy do not imply that both perspectives should be analysed independently. Indeed, the same institutions are subject to both normative and sociological legitimacy, since "whether an institution has the objective right to exercise power may depend in part on whether people subject to its authority it find it legitimate. ${ }^{38 "}$

However, one of the main criticisms in Global Governance remains the lack of an electoral underpinning to make binding decisions legitimate ${ }^{39}$. Democracy is commonly seen as the adequate system to provide an effective mechanism for accountability and to justify the use of authority ${ }^{40}$. Therefore, from this point of view, most decisions established by international institutions would be illegitimate, since international authorities are usually not democratically elected. Yet, that line of thought is inaccurate for one fundamental reason: it is possible to legitimately establish good governance prac-

34 COHEN, Harlan G; FOLLESSAL, Andreas; GROSSMAN, Nienke; ULFSTEIN, Geir. Legitimacy and International Courts - A Framework. Cambridge: Cambridge University Press, 2017. p. 4 35 COHEN, Harlan G,; FOLLESSAL, Andreas; GROSSMAN, Nienke; ULFSTEIN, Geir. Legitimacy and International Courts - A Framework. Cambridge: Cambridge University Press, 2017. p. 11

36 BUCHANAN, Allen; KEOHANE, Robert O. The Legitimacy of Global Governance Institutions Ethics \& International Affairs, 2006. p. 405.

37 VOETEN, Erik. Public Opinion and the Legitimacy of International Courts. Theoretical Inquiries in Law, 2013. p. 414

38 SCHAFFER, Johan Karlsson. Legitimacy, Global Governance and Human Rights Institutions: Inverting the puzzle. Cambridge: Cambridge University Press, 2013. p. 8

39 ESTY, Daniel. Good Governance at the Supranational Scale: Globalizing Administrative Law. New Haven: Yale Law Journal, 2006. p. 1507.

40 ESTY, Daniel. Good Governance at the Supranational Scale: Globalizing Administrative Law. New Haven: Yale Law Journal, 2006. p. 1507 tices even without direct elections ${ }^{41}$.

For instance, the United Nations provides eight essential characteristics for good governance practices: participation, consensual orientation, accountability, responsiveness, effectiveness, equitability, inclusiveness and the use of the rule of law ${ }^{42}$. It also understands that these activities require that public participation has due consideration, and that minorities voices are taken into account in the decision-making process. Those practices help to legitimize authority in the international scenario and to maximize the benefits of Global Governance ${ }^{43}$.

To that end, Esty argues that legitimacy in a global context can be achieved through different assets: efficacy and delivery of good results (result-based legitimacy), rigorous rulemaking (order-based legitimacy), checks and balances structures (systematic legitimacy), public dialogue (deliberative legitimacy) and procedural stability (procedural legitimacy) ${ }^{44}$. Those are the mechanisms that could help to remedy the absence of democratic elections in international bodies. In that sense, different institutions may be legitimate for different reasons. For instance, the UN General Assembly might justify its authority because of its inclusiveness, while an Arbitral Tribunal might support its impartiality and procedural rigor to justify its actions ${ }^{45}$.

According to Esty's proposal ${ }^{46}$, Result-Based Legitimacy derogates from the expertise of the policymaker and its capacity to generate social welfare benefits. That requires the ability to deliver good results with neutrality, focus and knowledge. The Organization for Economic Cooperation and Development (OECD), for instance, is known for its technical expertise. The intergovern-

${ }^{41}$ ESTY, Daniel. Good Governance at the Supranational Scale: Globalizing Administrative Law. New Haven: Yale Law Journal, 2006. p. 1516

42 UNITED NATIONS. What is Good Governance? Available at <https://www.unescap.org/sites/default/files/good-governance.pdf $>$

43 ESTY, Daniel. Good Governance at the Supranational Scale: Globalizing Administrative Law. New Haven: Yale Law Journal, 2006. pp. 1514.

44 ESTY, Daniel. Good Governance at the Supranational Scale: Globalizing Administrative Law. New Haven: Yale Law Journal, 2006. p. 1516

45 MENDES, Joanna; VENKZE, Ingo. Allocating Authority: who should do what in European and International Law- Introducing the Idea of Relative Authority. Hart Publishing, 2018. pp. 3-4.

46 ESTY, Daniel. Good Governance at the Supranational Scale: Globalizing Administrative Law. New Haven: Yale Law Journal, 2006. p. 1516 
mental organization implements a policy of data and information exchange, benchmark performances and review policy results. Additionally, it constantly organizes meetings with ministers to cooperate and discuss relevant issues. In a similar manner, the World Trade Organization (WTO) - even though it lacks public participation mechanisms - adopts technical processes in its Appellate Body, such as notices of appeal, consistent base of jurisprudence and rational mechanisms for decision making in order to increase its legitimacy ${ }^{47}$.

Alternatively, Order-Based Legitimacy derives from the need to clarify rules and impose order to a certain community, providing traditional structures and stability. The Systematic Legitimacy, on the other hand, requires institutions to adopt checks and balances structures in order to guarantee the rule of law. This might occur through the process of spreading responsibilities across different agents and international bodies, creating a system of cooperation among authorities. On the other hand, Deliberative Legitimacy enhances the debate in the rulemaking process. The main idea is that, due to the broad range of views, deliberation promotes a more rational, carefully constructed and improved decisions. Lastly, the Procedural Legitimacy requires that international agents act within the right process and follow the established rules to improve its outcomes.

Therefore, it is possible to ensure the legitimacy of international institutions regardless of the fact that their representatives are not democratically elected. Yet, in order to remedy the democratic deficit and improve its sociological legitimacy, institutions are encouraged to adopt good governance structures to engage in the public debate, establish orders and produce great outcomes.

\subsubsection{Accountability}

The lack of accountably also draws much criticism. Over the recent years, there has been a massive increase of international rules and decisions made by NSAs and international regulatory bodies. Along with the growing tendency of globalization, accountability deficits have been put into question by many global institutions, such

ESTY, Daniel. Good Governance at the Supranational Scale: Globalizing Administrative Law. New Haven: Yale Law Journal, 2006. pp. 1543-1549 as the IMF, WTO and the World Bank ${ }^{48}$. However, only weak - if any - accountability mechanisms have been properly implemented ${ }^{49}$. Nagel argues that it is common for national regimes to implement responsibility mechanisms but, when referring to a global regime, there is no similar responsibility mechanism of social justice for the citizenry of the states affected by the implemented decisions ${ }^{50}$.

As far as the United Nations are concerned, accountability is considered as one of the five critical principles in order to build good governance practices ${ }^{51}$. Krisch, for instance, states that there is a need for accountability whenever "a responsible power-wielder has such an impact on the autonomy and equality of individuals in the affected population that democratic regulation is warranted ${ }^{\prime 52}$. The Council of Europe defines accountability as the possibility of an agent to be liable and to give "account or explanation of actions and, where appropriate, to suffer the consequences (...) if it should appear that errors have been made ${ }^{153}$.

Schedler analyses the concept through two different perspectives: answerability and enforcement. The first one is related to the obligation to inform and provide details on the decisions, while the latter refers to the possibility of punishment in cases where the authority is caught in improper behaviour ${ }^{54}$. Thus, accountability in global governance should not only ensure that the decision-making process is transparent, but also guarantee the power to remove political actors in the global sphere. In other words, accountability in global governance depends not only on building transparent mecha-

48 LAFONT, Cristina. Accountability and global governance: challenging the state-centric conception of human rights. Taylor \& Francis, 2010. p. 193

49 SCHOLTE, Jan Aart. Civil Society and Democratically Accountable Global Governance. Blackwell Publishing, 2004. p. 1

50 NAGEL, Thomas. The Problem of Global Justice. Blackwell Publishing, 2004. pp. 139-40. As cited by LAFONT, Cristina. Accountability and global governance: challenging the state-centric conception of human rights. Taylor \& Francis, 2010. p. 197

51 UNITED NATIONS. Policy Note Global governance and global rules for development in the post-2015 era. United $\mathrm{Na}$ tions, 2014. p. 15

52 KINGSBURY, Benedict; KRISCH. Global Governance and Global Administrative Law in the International Legal Order. The European Journal of International Law, 2006. p. 6

53 EUROPEAN COMMISSION FOR DEMOCRACY THROUGH LAW. Report on the Democratic oversight of the Security Service. Council of Europe, 2007. p. 4.

54 SCHEDLER, Andreas. Conceptualizing Accountability. Lynne Rienner, 1999. pp. 13 - 15, as cited in HALE, Thomas N. Transparency, Accountability, and Global Governance. Brill, 2008. pp. $74-75$ 
nisms, but also on establishing clear commitments and goals, review processes and "follow-up" mechanisms to guarantee compliance. This means that the idea of accountability should not be seen as an end in itself, but rather as a mechanism to achieve good governance results ${ }^{55}$.

Additionally, Mendes argues that, while tools to secure accountability are essential for ensuring legitimacy in global governance, they do not provide us with any guidelines as to who should do what in the international legal system ${ }^{56}$. According to her, "accountability is concerned with who gives account to whom, with the question of how an actor gives account, and with which possible consequences". Thus, the concept of accountability is closely related to the distribution of power among different institutions and agents. As a consequence, there is still need for examining the issue of how responsibilities should be distributed between different international institutions and regulatory bodies.

For that reason, a well-functioning system of separation of powers, that provides the engagement between institutions, is essential to enhance accountability in the global system ${ }^{57}$. In this sense, global governance should not be merely based on the traditional and abstract idea of separation of powers, but rather on a realistic system of checks and balances based on what a particular institution can contribute with ${ }^{58}$. Therefore, the current tendency is to depart from a traditional tripartite division of powers and to move towards a concept of relative authority ${ }^{59}$. This idea indicates that global governance

55 UNITED NATIONS. Policy Note Global governance and global rules for development in the post-2015 era. United Nations, 2014. p. 15

56 MENDES, Joanna; VENKZE, Ingo. Allocating Authority: who should do what in European and International Law- Introducing the Idea of Relative Authority. Hart Publishing, 2018. 57 CAROLAN, Eoin; CURTIN, Deirdre. In Search of a New Model of Checks and Balances for the EU: Beyond Separation of Powers. In: Allocating Authority: who should do what in European and International Law- Introducing the Idea of Relative Authority. Hart Publishing, 2018. p. 72

58 Eoin Carolan, Deirdre Curtin, In Search of a New Model of Checks and Balances for the EU: Beyond Separation of Powers.In: Allocating Authority: who should do what in European and International Law- Introducing the Idea of Relative Authority. Hart Publishing, 2018. p. 54. See also MENDES, Joanna; VENKZE, Ingo. Allocating Authority: who should do what in European and International Law- Introducing the Idea of Relative Authority. Hart Publishing, 2018. p. 18.

59 MENDES, Joanna; VENKZE, Ingo. Allocating Authority: who should do what in European and International Law- Introducing the Idea of Relative Authority. Hart Publishing, 2018. should be articulated and not diffused. It is not about divisions, but connections ${ }^{60}$.

Certainly, the search for an effective alternative to overcome legitimacy and accountability concerns is a demanding task for international scholars due to the complex character of the global governance debate and structures. Nonetheless, although faced with sophisticated institutional particularities and constant political tensions, the European Union was able to adopt multiple governance reforms in the last decades as an attempt to minimize the democratic distress.

\section{The evolution of EU Governance: from gradual reforms towards an articulated method of governance}

When it comes to international governance, authority is often dispersed and fragmented. In worldwide organizations, intergovernmental rule-making, rule-application and rule-enforcement processes are inadequately supported and 'constitutionally restrained' ${ }^{61}$. Globally, there is no centralized regulatory institution; rather, a plurality of legal orders is arrayed horizontally and vertically, publicly and privately. ${ }^{62}$ In this context, discussing the distribution and organization of powers in the European Union can be insightful for global legitimacy claims due to EU's potentially instructive conceptual and practical developments ${ }^{63}$.

At the European level, the challenges concerning the division and allocation of authority are similar to those found at the international level, and this in spite of the EU's particular structure ${ }^{64}$. EU policy-making,

\section{p. 18}

60 MENDES, Joanna; VENKZE, Ingo. Allocating Authority: who should do what in European and International Law- Introducing the Idea of Relative Authority. Hart Publishing, 2018. p. 11.

61 PETERSMANN, Ernst-Ulrich (ed.), Multilevel Governance of Interdependent Public Goods Theories, Rules and Institutions for the Central Policy Challenge in the 21st Century, Florence: European University Institute, 2012, p. 196.

62 CAFFAGI, Fabrizio, CARON, David D. "Global Public Goods amidst a Plurality of Legal Orders: A Symposium". The European Journal of International Law Vol. 23 no. 3, 2012.

63 MENDES, Joanna; VENKZE, Ingo. Allocating Authority: who should do what in European and International Law- Introducing the Idea of Relative Authority. Hart Publishing, 2018. p. 6.

${ }^{64}$ MENDES, Joanna; VENKZE, Ingo. Allocating Authority: 
for example, involves multiple public and private actors at different levels of government ${ }^{65}$. When searching for alternatives to minimize legitimacy and accountability concerns in decision-making processes, one might consider EU's articulated models of governance which are oriented by good governance principles and a multilevel governance approach.

In response to the growing institutional criticism in the early 2000's and to the community's distrust in the EU's capacity to deal with worldwide problems, the Commission identified the need to reform the European governance ${ }^{66}$. At that time, EU traditional legal concepts were no longer sufficient to "make sense of the way things work let alone to regulate the policy making process" ${ }^{67}$. In an attempt to build more inclusive and accountable policy strategies, the Commission proposed good governance principles to guide Member States, local authorities and civil society towards a more effective system (3.1) ${ }^{68}$. Then, almost 20 years later, as the challenges persisted, initiatives of multilevel governance gained prominence in Europe (3.2).

\subsection{EU good governance principles}

The European Union defines governance as "the rules, processes, and behaviour by which interests are articulated, resources are managed, and power is exercised in society" ${ }^{69}$.

who should do what in European and International Law- Introducing the Idea of Relative Authority. Hart Publishing, 2018. p. 3-6. "Drawing lessons or inspiration does not mean to emulate". 65 BÖRZEL, T. A.; HEARD-LAURÉOTE, Karen. Networks in EU Multi-Level Governance: Concepts and Contributions. Journal of Public Policy, Vol. 29, No. 2, Networks in European Union Governance (Aug., 2009), pp. 135-151. According to the author, "While there is broad scholarly agreement that policy-making in the European Union (EU) involves a multitude of public and private actors at different levels of government, there is less agreement whether the EU should be conceptualized as a form of governance by networks or governance in networks".

${ }_{66}$ DEHOUSSE, Renaud. Misfits: EU Law and the Transformation of European Governance. In: JOERGES, Christian, DEHOUSSE, Renaud. Good Governance in Europe's Integrated Market. Oxford University Press, 2002.

${ }_{67}$ DEHOUSSE, Renaud. Misfits: EU Law and the Transformation of European Governance. In: JOERGES, Christian, DEHOUSSE, Renaud. Good Governance in Europe's Integrated Market. Oxford University Press, 2002, p. 227.

68 EUROPEAN COMMISSION. European Governance. European Union, COM (2001) 428, 2001. p. 7

69 EUROPEAN COMMISSION. Communication from the Commission to the Council, The European Parliament and the European Economic and Social Committee - Governance
Hence, influential change in the distribution of power and decision-making should be accompanied by governance changes. In the beginning of the 21 th century, there was a feeling that EU traditional legal categories have "ceased to adequately reflect the actual operation of the EU's machinery" ${ }^{\prime 70}$. The emergence of new actors - such as the EU administrative agencies ${ }^{71}$ - and the technical complexity of policy-making illustrated a "discrepancy between legal perceptions and functional realities" in the $\mathrm{EU}^{72}$.

In the context of governance reforms, the concept of 'good governance' gained importance. This concept may be understood through two complementary lenses: as a process of governance or as an outcome of governance. For instance, the United Nations Commission on Human Rights proposes five characteristics of good governance: transparency, responsibility, accountability, participation, and responsiveness ${ }^{73}$. This implies that good governance is more associated with the process and development of its policies than with its results. By contrast, the UN Resolution 2000/64 associates good governance practices with the "growth and sustainable buman development" ${ }^{\prime 4}$. The UN Resolution 2000/64 also notes that good governance practices will necessarily vary according to different societies' particular circumstances and needs.

Within the EU framework, the Committee of the

and Development. European Union, COM (2003) 615, 2013. para 1.4

70 DEHOUSSE, Renaud. Misfits: EU Law and the Transformation of European Governance. In: JOERGES, Christian, DEHOUSSE, Renaud. Good Governance in Europe's Integrated Market. Oxford University Press, 2002.

${ }^{71}$ For specific challenges involving accountability of EU agencies, see: VOS, Ellen. Making Informal International Law Accountable: Lessons from the EU. In: PAUWELYN, Joost; WESSEL, Ramses A; WOUTERS, Jan. Informal International Lawmaking. Oxford University Press 2012, p. 376.

72 DEHOUSSE, Renaud. Misfits: EU Law and the Transformation of European Governance. In: JOERGES, Christian, DEHOUSSE, Renaud. Good Governance in Europe's Integrated Market. Oxford University Press, 2002.

73 UNITED NATIONS HUMAN RIGHTS OFFICE OF THE HIGH COMMISSIONER. Good Governance and Human Rights. United Nations, 2008. as cited in BRADLEY, Andres; SLOCUM-BRADLEY, Nikki. Is the EU's Governance 'Good'? An assessment of EU Governance in its partnership with ACP States. UNU Institute on Comparative Regional Integration Studies Working Papers W-2010/1, 2006. p. 6.

74 BRADLEY, Andres; SLOCUM-BRADLEY, Nikki. Is the EU's Governance 'Good'? An assessment of EU Governance in its partnership with ACP States. UNU Institute on Comparative Regional Integration Studies Working Papers W-2010/1, 2006. p. 6. 
Regions (CoR) is an important institution for the implementation of good governance practices. The Charter for Multilevel Governance in Europe states that the CoR is committed to promote citizen participation, cooperate with public authorities, and strengthen institutional capacity building and transnational cooperation ${ }^{75}$.

The 2001 White Paper on European Governance presents five principles to achieve changes in governance practices: openness, participation, accountability, effectiveness and coherence ${ }^{76}$. In order to promote openness and participation, the Commission suggests that institutions work together with Member States to implement mechanisms of communication and use clear and understandable language for the general public. These practices might enhance the public's trust and confidence in the Union. Indeed, the Paper was open to public consultation for nine months - which already points to the Commission's commitment to promote openness and transparency in its procedures. The feedback was largely supportive of the mentioned principles, but other proposals, such as the addition of democratic legitimacy and subsidiarity principles $^{77}$, were also suggested.

However, these principles would not be effective without practical mechanisms and proposals. The Commission mentioned, for instance, that it would adopt standards for public consultation and publish them in a code of conduct by the end of $2001^{78}$. Furthermore, it also committed to the publication of guidelines on the use of expert advice in order to provide more accountability, plurality and integrity in its decisions ${ }^{79}$. The 2001 European Governance White Paper further suggests that "the Community Method" should be implemented to guarantee good governance practices within the Union. It presents the mechanism as a means to conciliate different interests of the Commission, Council and European Parliament ${ }^{80}$. According to the Commission, the method "ensures the fair treatment of all Member States from the largest to the smallest" and promotes the diversity and

\footnotetext{
75 THE COMMITTEE OF THE REGIONS. Charter for Multilevel governance in Europe. Title 2

${ }_{76}$ EUROPEAN COMMISSION. European Governance. European Union, COM (2001) 428, 2001. p.10

77 EUROPEAN COMMISSION. Report from the Commission on European Governance. European Union, 2003. p. 7.

78 EUROPEAN COMMISSION. European Governance. European Union, COM (2001) 428, 2001. p. 11

79 EUROPEAN COMMISSION. European Governance. European Union, COM (2001) 428, 2001, 19

80 EUROPEAN COMMISSION. European Governance. European Union, COM (2001) 428, 2001, 8
}

effectiveness of the Union.

The exercise of authority by EU agencies have also been subject of accountability and legitimacy concerns. The agencies are usually autonomous entities and often composed by national, European and stakeholders' representatives ${ }^{81}$. Stronger dialogue with civil society has become part of their regulatory strategy to stimulate "public confidence in EU action" ${ }^{22}$. The involvement of stakeholders and citizens can be traced as a parcel of good governance ${ }^{83}$. In addition, as an outcome of rich regulatory networks, the production of influential non-legally binding documents illustrates the performance of informal law-making in EU Agencies. As a consequence, a set of control and accountability mechanism have been designed and implemented in the last decades ${ }^{84}$.

Another example of the application of good governance principles can be seen in the 2018 Communication to the Commission. In the auspices of the 'Better Regulation agenda', the referred Communication indicates that the European Commission has, in addition to the information provided in its website, created several online consultation tools, such as 'Transparency Portal', 'Transparency Register', 'Financial Transparency System', 'Facilitating access to documents' ${ }^{85}$.

No doubt remains that principles of transparency

\footnotetext{
81 VOS, Ellen. Making Informal International Law Accountable: Lessons from the EU. In: PAUWELYN, Joost; WESSEL, Ramses A; WOUTERS, Jan. Informal International Lawmaking. Oxford University Press 2012, p. 372.

82 VOS, Ellen. Making Informal International Law Accountable: Lessons from the EU. In: PAUWELYN, Joost; WESSEL, Ramses A; WOUTERS, Jan. Informal International Lawmaking. Oxford University Press 2012, p. 379.

83 VOS, Ellen. Making Informal International Law Accountable: Lessons from the EU. In: PAUWELYN, Joost; WESSEL, Ramses A; WOUTERS, Jan. Informal International Lawmaking. Oxford University Press 2012, p. 379.

84 VOS, Ellen. Making Informal International Law Accountable: Lessons from the EU. In: PAUWELYN, Joost; WESSEL, Ramses A; WOUTERS, Jan. Informal International Lawmaking. Oxford University Press 2012, p. 376-80. According to Vos, three set of mechanisms have bene implemented: "instruments that precondition the exercise of powers by the agencies and/or their creation; instruments that monitor and review agency activities; and instruments that promote responsiveness of agencies. It is the author opinion that: "overall we can thus conclude that many arrangements to control and hold agencies accountable have been set in place. Shortcomings relate to the unfolding of accountability mechanisms in practice as well as the tensions between the Parliament, the Commission, the Council, and Member States, as well as the consequent multiplicity of controls of accountability lines."

85 EUROPEAN COMMISSION. European Governance. Brussels, COM (2018) 7703, 19,20
} 
and accountability are important to respond to legitimacy concerns. Good governance principles can be essential to achieve trust, especially for improving public administration in the Member States and making the public sector's management and accountability more effective ${ }^{86}$. However, according to Joana Mendes and Ingo Venzke's theory, they might not be sufficient to that end ${ }^{87}$. The authors affirm that the implementation of accountability and transparency mechanisms only access the legitimacy issue when the authority is exercised without control or visibility ${ }^{88}$. This means that such good governance principles might not address the institution's decision-making competences in the division and allocation of authority, neither take into consideration the dynamic relation between different institutions.

After almost 20 years since the debates on good governance started, challenges remained, and initiatives of 'multilevel' or 'multilayer' governance emerged in the EU. Whereas the 2001 White Paper on EU Governance prescribes five substantive principles underpinning good governance (openness, participation, responsibility, effectiveness and coherence), multilevel governance has essentially a procedural nature and was elaborated to ensure the implementation, maintenance and enhancement of these principles ${ }^{89}$.

\subsection{The European multilevel governance approach}

In the context of the EU, there are many connotations of the multilevel governance theory ${ }^{90}$, which relate to different phenomena ${ }^{91}$. The concept was ori-

86 GRIMHEDEN, Jonas, TOGGENBURG Gabriel N.. The Right to Good Administration in the Multilevel System of the European Union-A "Newish" Right Strengthening the Administrative Culture. Koninklijke Brill nv, Leiden, 2016.

87 MENDES, Joanna; VENKZE, Ingo. Allocating Authority: who should do what in European and International Law- Introducing the Idea of Relative Authority. Hart Publishing, 2018. p. 7.

88 MENDES, Joanna; VENKZE, Ingo. Allocating Authority: who should do what in European and International Law- Introducing the Idea of Relative Authority. Hart Publishing, 2018. p. 7. 89 THE COMMITTEE OF THE REGIONS. Multilevel Governance. European Union, 2009. p. 5

90 HORGA, Joan; FLORIAN, Gyula Laszlo. Multilevel Governance (MLG) And Subsidiary Principle In White Paper Of MLG Of The Committee Of The Regions (COR). Munich: University Library of Munich, MPRA Paper No. 44854, 2011. p.2.

91 PANARA, Carlo. Multi-Level Governance as a Constitu- ginally created by political scholars who were interested in understanding and explaining the functioning of EU decision-making processes. Subsequently, scholars understand that multilevel governance became a normative and a legal concept ${ }^{92}$.

In 2009, the European Committee of the Regions, an EU advisory board composed of regional and local authorities, prepared the White Paper on Multilevel Governance in order to reinforce partnership tools across Europe. It has defined multilevel governance (MLG) as "coordinated action by the European Union, the Member States and local and regional authorities, based on partnership and aimed at drawing up and implementing EU policies"'3. Among other goals, MLG should allow the Union to evaluate the impact of its directives on regional and local levels ${ }^{94}$. It also reassures the "community method" as the cornerstone of European Governance ${ }^{95}$.

This White Paper has a fundamentally "procedural" character as it lays down guidelines regarding how decisions are to be taken in the $\mathrm{EU}^{96}$. According to the Committee of the Regions: "MLG emerges, therefore, as a "method" or "approach": the appropriate method or approach, according to the CoR, for bringing together and coordinating the action of the different levels of government in the $E U$ multi-level system '. ${ }^{97}$ Taking the subsidiarity principle into account, MLG aims for the integration of different layers of government in policy and law making processes, considering the adoption of various mechanisms, such as consultation and territorial impact analyses. ${ }^{98}$

MLG departs from the premise that EU depends on the mode of governance and on various players' contributions in order to address legitimacy, efficiency and

tional Principle. HKJU-CCPA 16(4), 2016. p.706.

92 PANARA, Carlo. Multi-Level Governance as a Constitutional Principle. HKJU-CCPA 16(4), 2016. p.706.

93 THE COMMITTEE OF THE REGIONS. Scoreboard for Monitoring Multilevel Governance (MLG) at the European Union level. European Union, 2011

94 THE COMMITTEE OF THE REGIONS. Scoreboard for Monitoring Multilevel Governance (MLG) at the European Union level. European Union, 2011. p. 29.

95 THE COMMITTEE OF THE REGIONS. Scoreboard for Monitoring Multilevel Governance (MLG) at the European Union level. European Union, 2011. p. 8.

96 PANARA, Carlo. Multi-Level Governance as a Constitutional Principle. HKJU-CCPA 16(4), 2016. p.711.

97 PANARA, Carlo. Multi-Level Governance as a Constitutional Principle. HKJU-CCPA 16(4), 2016. p.711

98 THE COMMITTEE OF THE REGIONS. Multilevel Governance. European Union, 2009. p. 5 
visibility issues. ${ }^{99}$ Applying a multilevel approach to governance means going beyond participation and consultation, and further promoting a more dynamic system by ensuring greater responsibility for all actors involved (shared responsibility). Therefore, MLG aspires a complementary balance between institutional and partnership-based governance. ${ }^{100}$

Consequently, EU MLG should also involve interparliamentary cooperation and strengthening of law-making democratic legitimacy ${ }^{101}$. In fact, MLG dynamical character prevents it from being solely understood through the lens of the traditional division of powers ${ }^{102}$. According to the 2009 White Paper, having an institutional framework which involves different levels of government is not enough to guarantee good governance. That is because good cooperation between different legitimate political and democratic roles is vital and has to be based on trust and not on confrontation ${ }^{103}$.

The non-traditional EU structure of separation of powers can be an example of the dynamic multilevel governance approach. EU accountability mechanisms are based on apolitical arrangements, such as technical overview of comitology committees and the use of benchmarking, in which EU regulations and directives are continually revised to ensure a transparent and rational system of separation of powers ${ }^{104}$. This illustrates a kind of interactive accountability that does not focus on a limited tripartite division of functions.

Seen in these terms, Carolan and Curtin argue that the EU would highly benefit from a concept of sepa-

\footnotetext{
99 THE COMMITTEE OF THE REGIONS. Multilevel Governance. European Union, 2009. p. 4

100 THE COMMITTEE OF THE REGIONS. Multilevel Governance. European Union, 2009. p. 4.

101 THE COMMITTEE OF THE REGIONS. Multilevel Governance. European Union, 2009. p. 9.

102 THE COMMITTEE OF THE REGIONS. Multilevel Governance. European Union, 2009. p. 5.

103 THE COMMITTEE OF THE REGIONS. Multilevel Governance. European Union, 2009. p 8: "European democracy would be reinforced by more inclusive and flexible interinstitutional cooperation and by more sustained political cooperation between the various levels of power; European political parties, which are a particularly important element for strengthening the European political sphere and thus helping to develop a political culture of multilevel governance."

104 CAROLAN, Eoin; CURTIN, Deirdre. In Search of a New Model of Checks and Balances for the EU: Beyond Separation of Powers. In: Allocating Authority: who should do what in European and International Law- Introducing the Idea of Relative Authority. Hart Publishing, 2018. p. 73
}

ration of powers in accordance with empirical evidences of institutional practices and not on a general idea of division of functions ${ }^{105}$. This division of limits and competences among the institutions is best understood as the principle of institutional balance. Jean-Paul Jacqué argues that, according to this principle, institutions should act "within the limits of their competences"106. That does not imply, however, that legislators, when drafting treaties, are required to establish the exact tasks and weights that each institution should be given. According to Lenaerts and Verhoeven, despite the concept's imprecise contours, it plays an important role in inspiring a balanced government and in fighting against the democratic defi$\mathrm{cit}^{107}$. Therefore, the institutional balance system could be used to divide and articulate powers between different institutions in the international community.

Distributing functions is also essential for one logical reason: in most countries, it is impractical that the legislators, given their limited time and resources, make every decision. Thus, it might be necessary to delegate functions to an executive body. Likewise, in the EU, the legislature (the Council and the Parliament) cannot be responsible for all the highly technical and detailed-oriented regulations. For this reason, many decisions are delegated to an executive body (the Commission). Therefore, the concept of comitology refers to the idea that the Council confers certain implementing powers to the Commission that, along with the committees (with national representatives of states), engage in a rule-making process ${ }^{108}$.

Furthermore, a strict tripartite division would indicate that a decision made by one of the three main institutional organs (Parliament, Council and Commission) represented the final exercise of power. However, the reality is much different. For instance, when performing its functions, the Commission Hearing Officers in the

105 CAROLAN, Eoin; CURTIN, Deirdre. In Search of a New Model of Checks and Balances for the EU: Beyond Separation of Powers. In: Allocating Authority: who should do what in European and International Law- Introducing the Idea of Relative Authority. Hart Publishing, 2018. p.74, 75 106 JACQUÉ, Jean-Paul. The Principle of Institutional Balance. Common Market Law Review, 2004. p.383

107 LENARTS, Koen, VERHOEVEN, Amaryllis. Institutional Balance as a Guarantee for Democracy in EU Governance. . In: JOERGES, Christian, DEHOUSSE, Renaud. Good Governance in Europe's Integrated Market. Oxford University Press, 2002.

108 WEILER, J.H.H; KOCJAN, M. European Community System: Comitology. Teaching Material for the Jean Monnet Center at NYU School of Law, 2004. p. 5 
EU are faced with messy institutional structures and are forced to cross the lines of a theoretical idea of a tripartite division. Likewise, autonomous actors, such as the European Central Bank and the Court of Justice of the European Union, are compelled to engage in articulation processes with other actors in order to implement their policies and decisions ${ }^{109}$.

In this context, MLG gains importance: developing an efficient system of checks and balances depends on how different institutions interact with one another. The EU comitology system is a way of demonstrating this non-centralized interaction. It includes about 220 committees that discuss and decide on all European regulations. The key purpose of this system is to find the most technical choice that benefits the Union over the national government's individual interests ${ }^{110}$. This shows that these sub-central processes of decision-making are examples that a limited tripartite division is not sufficient to be applied to EU's dynamical reality. That system is important not only for practical reasons - to avoid burdening the workload of the Council -, but also to provide more legitimacy to the regulatory process. Because of its numerous technical processes and national government's contributions, comitology is central to ensure democracy in the Union, and its exercise of power is of fundamental importance ${ }^{111}$.

In order to put multilevel governance into practice, in 2011 the Committee of the Regions required its own participation in agreements between the European Parliament, the Council and the European Commission to deal with evaluation and consultation mechanisms, within the 'Better Lawmaking' action. It also called on the European Commission to "ensure ready access for local and regional authorities to comitology and to groups of experts

\footnotetext{
109 CAROLAN, Eoin; CURTIN, Deirdre. In Search of a New Model of Checks and Balances for the EU: Beyond Separation of Powers. In: Allocating Authority: who should do what in European and International Law- Introducing the Idea of Relative Authority. Hart Publishing, 2018. p. 55

110 CAROLAN, Eoin; CURTIN, Deirdre. In Search of a New Model of Checks and Balances for the EU: Beyond Separation of Powers. In: Allocating Authority: who should do what in European and International Law- Introducing the Idea of Relative Authority. Hart Publishing, 2018. p.75

111 ST. CLAIR, Bradley Kieran. Comitology and the Law: through a glass, darkly. Common Market Law Review,1992. p. 720, as cited in WEILER, J.H.H; KOCJAN, M. European Community System: Comitology. Teaching Material for the Jean Monnet Center at NYU School of Law, 2004. p.7
}

responsible for implementing the plan". ${ }^{112}$ Moreover, for the purposes of effectively implementing MLG, the Committee of the Regions created the Scoreboard on Multilevel Governance, which monitors, on a yearly basis, the impacts and developments of MLG in the European Union $^{113}$.

Another example of alternative and multilevel interaction can be seen as far as EU agencies are concerned. Indeed, various instruments have been tailored to fit specific agency's needs to promote higher transparency and accountability. Overall, the "vertical form of political, democratic accountability, public accountability, and redundancy accountability" have been combined with horizontal mechanisms, such as codes of conduct and multiple actors' participation in the decision-making process $^{114}$.

\section{Conclusion}

The expansion of the global governance regime, together with the increased participation of NSAs in international law-making raises questions about the sufficiency of traditional sources of international law. The new scenario not only instigates the investigation of the impact of normativity changes, but also strengthen the search for possible responses to the events that do not fit into the existing formal categories. Abandoning a state-centred paradigm, however, should not be confused with the idea that authorities or actors in the global governance structure cannot be held accountable ${ }^{115}$. Rather, it calls for a change of perspective, in which the focus is on the exercise of public authority by a state, a hybrid or a private agent that affects somebody's freedom ${ }^{116}$; and therefore, should be regulated.

112 THE COMMITTEE OF THE REGIONS. Multilevel Governance. European Union, 2009. p. 21.

113 THE COMMITTEE OF THE REGIONS. Scoreboard for Monitoring Multilevel Governance (MLG) at the European Union level. European Union, 2011. p. 2.

114 VOS, Ellen. Making Informal International Law Accountable: Lessons from the EU. In: PAUWELYN, Joost; WESSEL, Ramses A; WOUTERS, Jan. Informal International Lawmaking. Oxford University Press 2012, p. 381.

115 VON BOGDANDY, Armin; PHILIPP, Dann; GOLDMAN, Matthias. Developing the Publicness of Public International Law: Towards a Legal Framework for Global Governance Activities. German Law Journal, 2009. p. 1380

116 VON BOGDANDY, Armin; PHILIPP, Dann; GOLDMAN, Matthias. Developing the Publicness of Public International 
From a global governance perspective, how can International Law address the emergence of new participants which is necessarily followed by democratic concerns? In the current framework of international regulation, the European instructive conceptual and practical developments can be insightful for addressing global challenges, as similar normative problems appear both at the international and regional levels. In order to minimize legitimacy and accountability concerns, one might look for EU articulated models of governance that follow good governance principles and reach for multilevel governance system specially designed for particular regulatory demands.

As far as global governance is concerned, since there is no global authority to compel actors to accomplish global achievements, policy interdependence and international cooperation seem to be an interesting alternative. International law could also support and facilitate the integration within institutions - typically fragmented-and create common norms and rules favorable to the provision of global public goods ${ }^{117}$. Yet, this should be guided by a multilevel governance approach, since the promotion of goods depends on State's voluntary commitment and compliance, on the sense of collective purpose, and on national systems ${ }^{118}$.

The European model for distribution of powers and accountability may not be ideal for all types of regulatory regimes in the global sphere. Nonetheless, it illustrates a non-tradition institutional setup, which is not shaped to respond to a tripartite division of powers closely connected to specific government branches ${ }^{119}$. Within concrete practices, the EU insightful system divides and connects authority in specific ways that aims to combine each institution's assets to democratic governance $^{120}$, by applying good and multilevel gover-

Law: Towards a Legal Framework for Global Governance Activities. German Law Journal, 2009. p. 1376.

117 See KAUL, Inge; GRUNBERG, Isabelle; STERN, Marc A. (eds). Global Public Goods: International Cooperation in the 21th Century. OUP, 1999,

118 See PETERSMANN, Ernst-Ulrich, Multilevel Governance of Interdependent Public Goods Theories, Rules and Institutions for the Central Policy Challenge in the 21st Century, Florence: European University Institute, 2012.

119 MENDES, Joanna; VENKZE, Ingo. Allocating Authority: who should do what in European and International Law- Introducing the Idea of Relative Authority. Hart Publishing, 2018. p. 18.

120 MENDES, Joanna; VENKZE, Ingo. Allocating Authority: who should do what in European and International Law- In- nance principles. For both European and International purposes, good governance and multilevel governance approaches may assist the search for appropriate solutions to the challenges of international regulation in times of normativity change.

\section{References}

\section{Books}

ALVAREZ, Jose E. The New Treaty Makers. Boston: Boston College International \& Comparative Law Review, 2002.

BUCHANAN, Allen; KEOHANE, Robert O. The Legitimacy of Global Governance Institutions Ethics \& International Affairs, 2006.

d'ASPREMONT, Jean. Non-State Actors in International Law: Oscillating between Concepts and Dynamics. Routledge, 2011.

D'ASPREMONT, Jean. From a Pluralization of International Norm-making Processes to a Pluralization of the Concept of International Law. In: PAUWELYN, Joost; WESSEL, Ramses A; WOUTERS, Jan. Informal International Lawmaking. Oxford University Press 2012.

DEHOUSSE, Renaud. Misfits: EU Law and the Transformation of European Governance. In: JOERGES, Christian, DEHOUSSE, Renaud. Good Governance in Europe's Integrated Market. Oxford University Press, 2002, p. 227.

HALE, Thomas N. Transparency, Accountability, and Global Governance. Brill, 2008.

JACQUÉ, Jean-Paul. The Principle of Institutional Balance. Common Market Law Review, 2004.

KAUL, Inge; GRUNBERG, Isabelle; STERN, Marc A. Global Public Goods: International Cooperation in the 21th Century. OUP, 1999.

LAFONT, Cristina. Accountability and global governance: challenging the state-centric conception of human rights. Taylor \& Francis, 2010.

troducing the Idea of Relative Authority. Hart Publishing, 2018. pp.18-22. 
MENDES, Joanna; VENKZE, Ingo. Allocating Authority: who should do what in European and International Law- Introducing the Idea of Relative Authority. Hart Publishing, 2018.

NAGEL, Thomas. The Problem of Global Justice. Blackwell Publishing, 2004.

PETERSMANN, Ernst-Ulrich. Multilevel Governance of Interdependent Public Goods Theories, Rules and Institutions for the Central Policy Challenge in the 21st Century, Florence: European University Institute, 2012, p. 196.

REUS-SMIT, Christian. International Crises of Legitimacy. International Politics, 2007.

SCHAFFER, Johan Karlsson. Legitimacy, Global Governance and Human Rights Institutions: Inverting the puzzle. Cambridge: Cambridge University Press, 2013.

SCHEDLER, Andreas. Conceptualizing Accountability. Lynne Rienner, 1999.

SCHOLTE, Jan Aart. Civil Society and Democratically Accountable Global Governance. Blackwell Publishing, 2004.

VOETEN, Erik. Public Opinion and the Legitimacy of International Courts. Theoretical Inquiries in Law, 2013.

VOS, Ellen. Making Informal International Law Accountable: Lessons from the EU. In: PAUWELYN, Joost; WESSEL, Ramses A; WOUTERS, Jan. Informal International Lawmaking. Oxford University Press 2012.

ZURN, Michael. A Theory of Global Governance: Authority, Legitimacy, and Contestation. Oxford University Press, 2018.

ZYBERI, Gentian. Non-State Actors from the Perspective of the International Law Commission. Routledge, 2011.

\section{Articles}

ANDERSON, Kenneth. Global Governance: The Problematic Relationship between Global Civil Society and the United Nations. WCL Research Series, 2008.

ARTS, Bas,: Non-state actors in global governance: Three faces of power, Preprints aus der Max-Planck-
Projektgruppe Recht der Gemeinschaftsgüter, No. 2003/4, Max-Planck-Projektgruppe Recht der Gemeinschaftsgüter, Bonn, 2003.

ARTS, Bas. Non-State Actors in Global Governance: Three Faces of Power. Max-Planck-Projektgruppe Recht der Gemeinschaftsgüter, 2003.

BORBOSA, Luiza Nogueira; MOSCHEN, Valesca R. B. O direito transnacional ("global law") e a crise de paradigma do estado-centrismo: é possível conceber uma ordem jurídica transnacional? Revista de Direito Internacional, v. 13, n. 3, 2016.

BÖRZEL, T. A.; HEARD-LAURÉOTE, Karen. Networks in EU Multi-Level Governance: Concepts and Contributions. Journal of Public Policy, Vol. 29, No. 2, Networks in European Union Governance (Aug., 2009), pp. 147.

BRADLEY, Andres; SLOCUM-BRADLEY, Nikki. Is the EU's Governance 'Good'? An assessment of EU Governance in its partnership with ACP States. UNU Institute on Comparative Regional Integration Studies Working Papers W-2010/1, 2006.

CAFFAGI, Fabrizio, CARON, David D. "Global Public Goods amidst a Plurality of Legal Orders: A Symposium". The European Journal of International Law Vol. 23 no. 3, 2012.

CAROLAN, Eoin; CURTIN, Deirdre. In Search of a New Model of Checks and Balances for the EU: Beyond Separation of Powers. In: MENDES, Joanna; VENKZE, Ingo (eds.) Allocating Authority: who should do what in European and International Law. Hart Publishing, 2018.

COHEN, Harlan G; FOLLESSAL, Andreas; GROSSMAN, Nienke; ULFSTEIN, Geir. Legitimacy and International Courts - A Framework. Cambridge: Cambridge University Press, 2017.

D'ASPREMONT, J. Non-state actors in international law: oscillating between concepts and dynamics. In: D'ASPREMONT, J. (ed.). Participants in the International Legal System. Abingdon: Routledge, 2011.

ESTY, Daniel. Good Governance at the Supranational Scale: Globalizing Administrative Law. New Haven: Yale Law Journal, 2006.

GIERTL, Adam; LAZOECAKOVÁ, Tímea. The Role of Non-Governmental Organizations in International Law-making. Czech Yearbook of Public \& Private 
International Law, v.9, 2018.

GRIMHEDEN, Jonas, TOGGENBURG Gabriel N.. The Right to Good Administration in the Multilevel System of the European Union-A "Newish" Right Strengthening the Administrative Culture. In: ZHANG, Wei, LI, Ruoyu; YAN, Zihan. Human Rights and Good Governance, v.1, Koninklijke Brill nv, Leiden, 2016.

HORGA, Joan; FLORIAN, Gyula Laszlo. Multilevel Governance (MLG) And Subsidiary Principle In White Paper Of MLG Of The Committee Of The Regions (COR). Munich: University Library of Munich, MPRA Paper No. 44854, 2011.

KINGSBURY, Benedict; KRISCH. Global Governance and Global Administrative Law in the International Legal Order. The European Journal of International Law, 2006.

KRISCH, Nico; KINGSBURY, Benedict. The Emergence of Global Administrative Law. In: Law and Contemporary Problems, vol. 68, 2005, p. 15-61.

NASSER, Salem H.. Direito Global em Pedaços: Fragmentação, Regimes e Pluralismo. Revista de Direito Internacional, v. 12, n. 2, 2015.

MENDES, Joanna; VENKZE, Ingo. Allocating Authority: who should do what in European and International Law- Introducing the Idea of Relative Authority. In: MENDES, Joanna; VENKZE, Ingo (eds.) Allocating Authority: who should do what in European and International Law. Hart Publishing, 2018.

PANARA, Carlo. Multi-Level Governance as a Constitutional Principle. In: PANARA, Carlo (ed.) The Subnational Dimension of the EU, Springer International Publishing, 2016.

POSTIGA, Andréa Rocha. A emergência do direito administrativo global como ferramenta de regulação transnacional do investimento estrangeiro direto. Brasília: Revista de Direito Internacional, 2013.

ST. CLAIR, Bradley Kieran. Comitology and the Law: through a glass, darkly. Common Market Law Review,1992.

VON BOGDANDY, Armin; PHILIPP, Dann; GOLDMAN, Matthias. Developing the Publicness of Public International Law: Towards a Legal Framework for Global Governance Activities. German Law Journal, 2009.
WAT'T, HORATIA MUIR. "Party Autonomy" in international contracts: from the makings of a myth to the requirements of global governance. European Review of Contract Law n. 3, 2010.

WEILER, J.H.H; KOCJAN, M. European Community System: Comitology. Teaching Material for the Jean Monnet Center at NYU School of Law, 2004.

WEISS, Thomas G.; SEYLE, Conor D.; COOLIDGE, Kelsey. The Rise of Non-State Actors in Global Governance Opportunities and Limitations. One Earth Future Foundation Discussion Paper, 2013.

XAVIER JUNIOR, Ely Caetano; BRANDÃO, Clarissa. Desafios Globais Contemporâneos: Cenário de Convergências no Direito Internacional. Revista Direito GV 5(2), 2009.

\section{International Documents}

EUROPEAN COMMISSION FOR DEMOCRACY THROUGH LAW. Report on the Democratic oversight of the Security Service. Council of Europe, 2007. p. 4.

EUROPEAN COMMISSION. Communication from the Commission to the Council, the European Parliament and the Economic and Social Committee, Participation of Non-State Actors in EC Development Policy. Brussels, 07.11.2002, COM (2002). 598.

.Communication from the Commission to the Council, The European Parliament and the European Economic and Social Committee - Governance and Development. European Union, COM (2003) 615, 2013.

European Governance. Brussels, COM (2018) 7703.

.European Governance. European Union, COM (2001) 428, 2001.

.Report from the Commission on European Governance. European Union, 2003.

INTERNATIONAL LAW ASSOCIATION. Committee on Non-State Actors Report of the 2016 Johannesburg Conference;

.Committee on Non-State Actors Report of the 2012 Sofia Conference. 
.Committee on Non-State Actors Report

of the 2010. Hague Conference.

THE COMMITTEE OF THE REGIONS. Charter for Multilevel governance in Europe. Title 2

.Multilevel Governance. European

Union, 2009.

.Scoreboard for Monitoring Multilevel

Governance (MLG) at the European Union level.

European Union, 2011.

UNITED NATIONS HUMAN RIGHTS OFFICE OF THE HIGH COMMISSIONER. Good Governance and Human Rights. United Nations, 2008.

UNITED NATIONS. Policy Note Global governance and global rules for development in the post2015 era. United Nations, 2014. p. 15

What is Good Governance? Available at <https://www.unescap.org/sites/default/files/goodgovernance.pdf $>$ 
Para publicar na Revista de Direito Internacional, acesse o endereço eletrônico www.rdi.uniceub.br ou www.brazilianjournal.org.

Observe as normas de publicação, para facilitar e agilizar o trabalho de edição. 